\title{
The Effect of Audiobook on Reading Comprehension of the Eleventh Grade Students of SMA Negeri 2 Buru
}

\author{
Abd. Rahman \\ rahmanabd716@gmail.com \\ University of Iqra Buru \\ Ibnu Hajar \\ Ibnuhjr423@gmail.com \\ University of Iqra Buru
}

\begin{abstract}
The audiobook does not only involves multiple senses of the students, but also the inclusion of its speech, helping them to improve their comprehension. This study sought to investigate the effects' of audiobook on students' reading comprehension, and to find out students' interest in audiobooks on the teaching of reading. The mixed method called the Quanqual model applied at this study. Some sixty eleventh-grade students participated, and data were collected by employing reading comprehension tests and questionnaires (open-ended questions). The quantitative data analyzed using paired and independent sample t-test through SPSS 20 Version, and the qualitative data analyzed through an open-coding technique. The use of audiobook was more effective than the non-audiobook. It is proven by the comparison of the mean score from both of the groups which $(68.00>48.80)$. The p-value in the post-test is .000 , and the level of significance is $\alpha 0.05$, the $\mathrm{p}$-value is smaller than $\alpha(.000<0.05)$. The hypothesis testing found that $\mathrm{t}$-value $=14.699$ was higher than $\mathrm{t}$-table $=2.045(\mathrm{p}=.000, \mathrm{df}=29)$; it means that Ha was accepted, and Ho was rejected. Another, the students are interested in using audiobooks because it stimulating, challenging, available, powerful and innovative in the reading activity.
\end{abstract}

Keywords: Audiobook, Reading Comprehension, Student Interest.

\section{INTRODUCTION}

The main target of reading is to understand the contents of the text, in fact many students still have difficulty in comprehending it, even they have been received intensive teaching on their reading classes. Consequently, this issue has become the greatest constraint of the EFL learners' in all time. As the foreign language learners', students' are facing severe trouble when they read and comprehend the English texts (Salikin, Bin-Tahir, Kusumaningputri, \& Yuliandari, 2017). Moreover, students lack interest in reading has lowered their reading comprehension skills, as a result, the descriptive, recount, narrative, analytical exposition, explanation, procedures, news items texts in the context of interpersonal, transactional, special functional, and functional which contains social functions, structures, and linguistic elements have become difficult to understand.

The Senior High School students in Kabupaten Buru Maluku are also having the same problem, and it is proven by the decline of their reading achievements each year. The National Examination Report (2019) has confirmed that the average score of students in the English reading comprehension test on the annual examination was 43.30 or less than 55.00 . This fact was implied that students reading comprehension skills are still low than the national standard. That is because of the EFL learners there found reading in English is entirely different from reading in their first language, so they have always encountered some intricate problems, e.g., the different linguistic aspects, the lexical, and the syntactic elements of English text they have read.

Several studies focused on the various factors that affected reading comprehension in English as a foreign language. According to Kasim \& Raisha (2017) the socio-cultural 
complexities are influencing students' to comprehend the context of EFL materials. There is a direct correlation between learners' attitudes toward reading and their actual reading behaviors, which are the key to comprehension. Moreover, the background knowledge of students, interests, motivation, purposes, and attitudes had directly influenced students reading comprehension ability (Aditomo \& Hasugian, 2018). The interest has the power to affect reading comprehension (Renandya, 2015). The learners, on the other side, with positive attitudes toward reading will accordingly comprehend the text better than learners with negative attitudes (Delfi \& Yamat, 2017; Habók, Magyar, \& Hui, 2019; Lin, 2010; Ulu, 2017).

The EFL teachers must be paying attention to encourage their students in reading comprehension activity. Jabu \& Muliati (2019) mentioned that to foster reading comprehension ability, one of the efforts that can be given is to present the pleasurable materials by using technology. The ELLs motivated intrinsically in reading comprehension if reading strategy and materials were attractive to learn, so the teaching of reading become more efficient by presenting an exciting content or a challenging task (Mistar, Zuhairi, \& Yanti, 2016; Ur, 1999). Students need new material to motivate them in reading in order they can easily remember and comprehend what they have learned (Gilakjani \& Sabouri, 2016; Pardede, 2006, 2019). For that reason, if the students' are interested in what is being taught, they are motivated to seek more information.

In the 2020s, there are many pedagogical advantages of using online and offline ecreative tools to mediate ELLs learn reading comprehension effectively. The technology has been combined textbook materials and reading aloud strategies to improve ELLs reading comprehension. Broughton, Brumfit, Flavel, Hill, \& Pincas, (2003) highlighted that by the involvement of visuals such as the use of pictures, diagrams, charts, models, and audio aids to reading may help to foster better understanding. A new literacies approach to read, among many, the audiobook is a viable intervention to encourage readers to read (Thooft, 2012). Moreover, by using the integration of both digital reading on audiobook can be promoted students' comprehension, and develop their literacy experience (Larson, 2015). Also, the audiobook is not only strengthening young people's interest in reading, but it also helps struggling readers keep plugging away and eventually master the fantastic art of reading a book (Baird, n.d.).

The advantages of audiobooks' for EFL learners are include spoken by native speakers, perfect articulation and pronunciation, the best alternative for reading, accessible anytime, anywhere, and free online resources. The audiobooks are effective in enhancing EFL students' receptive skills, that is because of the similar skills necessary to listening comprehension can be applied to reading comprehension (Vernon, 2015). Besides, the audiobooks are not only contributed to promoting the higher-level aspects of the reading process but also facilitated reading motivation for adolescents (Moore \& Cahill, 2016).

\section{LITERATURE REVIEW}

In 1931 one of the US Congress's demands to the National Library Service (NLS ) was the recording materials must be prepared to help the Blind and Physically Handicapped (BPH) called talking books. The talking books were initially merging from entertainment and communication, then soon famously recognized by its users as the audiobook. According to Alsamadani (2017) mentions that the audiobook was explicitly designed for impaired people to enable them to read through their ears. The audiobook has consisted of some literary works, such as an oral tradition, including folktales, poetry, and drama. In the early time of its emergence, the audiobooks were using to inform history, life experiences, and traditions of each generation to the next. Interestingly the audiobooks were narrated by the English native speaker voluntarily, who attracting audiences for their reading(Whittingham, Huffman, Christensen, \& McAllister, 2013).

The benefits of audiobooks for English learners are; can provide an example of fluent reading and exposure to patterns, intonation, expressions, different accents, dialects, and pronunciation of English (Ayunda, 2013). Meanwhile, the dramatized audiobooks can increase students' interest in the text and allow readers to enjoy a book even if it is above their reading 
level. Furthermore, with audiobook and their text, students' will have a multisensory approach to read(Kartal \& Simsek, 2017). Also, the audiobook supports auditory learners' and helps them with literacy development to improve comprehension of the texts (Ryan Wagar, 2016).

Some previous studies revealed that audiobooks significantly improve students' receptive skills. Montgomery (2009) in his study found that both English language learners' and native English speakers reading and academic performance have been improved using audiobooks in their classroom. Moreover, audiobooks in improving fluency and instilling students' literary skills have concluded that using audiobooks in primary education may improve language competence and literary skills (Alcantud-Díaz \& Gregori-Signes, 2014). The more challenging story in audiobooks becomes the more comprehensible story to the students, it is because as they listen, they began to understand the structure of the written language convention, and its vocabulary(Casbergue \& Harris, 1996).

Reading and listening to text has certain advantages, especially to students who struggle to focus on the reading activities. When students read and listen, they gain a deeper understanding of the English language (syntax, pronunciation, emphasis, etc). Gunduz (2006) highlighted that students' who listened to the audiobook have better reading comprehension skills. Furthermore, on the investigation of audiobooks' effects on listening comprehension and students' views about using audiobooks in classroom settings, audiobooks can also be used as supporting materials in advanced foreign language reading and listening classes (Kartal \& Simsek, 2017; Talalakina, 1989). Listening while reading provides a multisensory reading experience and can eliminate frustrations for students who have difficulties with text-only materials(Woodall, 2010).

The integration of audiobooks at all grade levels across the curriculum has given great teaching flexibility. The audiobooks can be used at the primary, secondary, middle, and high school and university levels (Stevens, Walker, \& Vaughn, 2017). That is because of the vast differences between reading with audiobooks and traditional reading aloud, e.g., firstly, reading by audiobooks is not restricted to time and space, it can be done on the portable devices everywhere; secondly, reading becomes more enjoyable, because the good stories are narrated by famous actors professionally, even the authors themselves, and giving students an accurate word pronunciation through its native speakers' narrators, because of its ease and simplicity. Moreover, the combination of listening and reading has increasing fluency. Listening and following by the reading text builds decoding skills and vocabulary to improve reading ability(Cahyono, 2009). The most useful online audiobooks for the English Language Learning mentioned as below;

- www.getaudiobooksonline.com

- download-free-audio-books.com/ audio,

- www .audiobooksforfree.com,

- www.audible.com,

- www.audiopub.org,

- www.audiofilemagazine.com,

- www.recordedbooks.com,

- www.librivoks.com,

- http://www.jiggerbug.com,

- www.readingrockers.org,

- www .leamingthroughlistening.org/sitedata/docs/t eaching tipsword/,

- http://dmoz.org/shopping/publications/books/ audio.

- https://lvcenglish.com/

- https://www.digitalbook.io/

Reading comprehension is necessary because it provides experience, expanding the horizons and insights into thinking to gain a deeper understanding. According to Hall (1989) reading comprehension is the essence of students' reading activity. Reading could be the basis of the other skills of the language (Abukhattala, 2013). However, as a receptive skill, reading is an intricate process, and it simultaneously involving many elements. Krashen (1982) in his second 
language acquisition theory states that the readers should have the capability to discriminate their perception of aspects of the codes, which formed as alphabetical letters, symbols, or signs according to the original code and the language writing system. The reader should know the meaning of the vocabulary and the word related to the text, that is, the reader should have an innate syntactic structure of the language of the original code. After the elements come as an association, finally, the reader comprehends the meaning of the text they have read (Pearson \& Cervetti, 2015). Therefore, through the reading comprehension process students' will understand the language context, obtain new information, synthesize, interpret, and evaluate reading texts from the learning resources they have learned.

As the goal-oriented process Grellet (1981) defined reading comprehension is an active cognitive process that involves reasoning to get meaning from a written text and understanding it deeply, effectively, and comprehensively. This process is involved in reader construction of a context to help him to sense out in a text. Reading comprehension abilities are quite complex and vary in numerous ways depending on tasks, motivations, goals, and language abilities. On the other side, the reading comprehension on the Indonesian Senior High School level of education is demanding students to comprehend the meaning of the text. Those texts include self-identity, announcement, recount, narrative, song, invitation, letter, procedure, factual report, analytic exposition, biography, and the last is the news text. Grabe \& Stoller (2013) were classified the significant differences exist among the complex nature of reading and, the various ways of reading as mentioned below;

Purposes for reading

- Reading to search for simple information

- Reading to skim quickly

- Reading to learn from texts

- Reading to integrate information

- Reading to write (or to search for information needed for writing)

- Reading to critique texts

- Reading for general comprehension

Components of reading

- Working memory processing

- Lower-level components

- Lexical access

- Syntactic parsing

- Semantic proposition formation

- Higher-level components

○ Text model of comprehension

- Situation model of reader interpretation

- Background knowledge use and inferencing

Processes required for fluent reading

- A rapid process

- An efficient process

- An interactive process

- A strategic process

- A flexible process

- An evaluating process

- A purposeful process

- A comprehending process

- A learning process

- A linguistic process

Models of reading

- Metaphorical models of reading

- Bottom-up models 
○ Top-down models

- Interactive models

- Specific models of reading

- Interactive compensatory model

- Word recognition model

- Simple view of reading model

- Dual-coding model

The sequence of reading comprehension strategies are arranged as; (1) vocabulary knowledge, (2) activating prior knowledge, (3) pre-reading previewing and predicting, (4) previewing and predicting text, (5) mental imaging, (6) self-questioning, (7) summarizing, (8) semantic mapping. This current study almost has similarities with some of the scientific works mentioned previously. Yet, this study not only focused on the investigation of audiobooks' effects on reading comprehension of the eleventh- grade students of SMA Negeri 2 Buru, but it also aimed to discover students' interest in audiobooks on the teaching of reading. It is believed that the results of this research give many practical advantages in the EFL field, especially for English teachers, students, ELT practitioners, and the next researcher who wants to dig audiobooks in the other skills of English. Therefore, this study answers the following two research questions.

RQ1. Do audiobooks affect the reading comprehension of the eleventh-grade students of SMA Negeri 2 Buru?

RQ2. What is the students' interest in audiobooks in teaching reading comprehension?

This study has two hypothesis need to be answered. (1) Null Hypothesis Ho: Audiobooks does not affect the reading comprehension of the eleventh-grade students' of SMA Negeri 2 Buru, and (2) Alternative Hypothesis Ha: Audiobooks affect the reading comprehension of the eleventh-grade students of SMA Negeri 2 Buru.

\section{METHOD}

In this study, a mixed-method called the Quan-qual model is specifically used to investigate the effects of audiobooks on students' reading comprehension skills and identify students' interest in audiobooks on the teaching reading process. This design has to allow a researcher to elaborate on both quantitative and qualitative data found to be analyzed to understand better the phenomenon under investigation (Gay, Mills, \& Airasian, 2012). The quantitative approach using the non-equivalent control group pretest-posttest quasi-experimental design as drawn below;

\begin{tabular}{lccc} 
& Pre-test & Treatment & Post-test \\
EG & $0^{1}$ & $\mathrm{X}^{1}$ & $0^{2}$ \\
\hline CG & $0^{1}$ & $\mathrm{X}^{2}$ & $0^{2}$
\end{tabular}

On the other side, the qualitative approach by using questionnaire "open-ended questions. The participants were sixty eleventh-grade year students' of SMU Negeri 2 Buru, which was determined using random sampling and the purposive sampling technique. The researcher selected thirty students in the eleventh-grade of MIA $^{1}$ as the experimental group, and some thirty students were also selected from the eleventh-grade of MIA ${ }^{3}$ as the control group. Due to the coronavirus disease situation, this research is fully conducted by following a pandemic protocol. To gain the quantitative data, reading comprehension tests adapted, consisting of twenty-five multiple-choice questions used to measure students' reading ability, then it classified into the rate of reading comprehension referred by (Buzan, 2003), and followed by the open-ended questions composed of six questions distributed among 30 students in the experimental group. The pre-test and the post-test data were gathered from both experimental and the control groups, and the calculation is done by the formula based on (Asrul, Ananda, \& Rosinta, 2014).

$$
\begin{aligned}
& \text { B } x \frac{100}{S=} \\
& S=\quad \text { = The scoring of the test } \\
& \text { B } \quad=\text { The students' correct answer }
\end{aligned}
$$


$\mathrm{N} \quad=$ The total number of items

The qualitative data gathered by open-ended questions then analyzed through open coding technique that focuses on the conceptualization, categorization by identifying, naming, and describing phenomena of the data(Corbin \& Strauss, 2008 ; Atmowardoyo, 2018).

\section{RESULT AND DISCUSSION \\ Findings}

1. Students' Reading Comprehension Ability

Figure 1. The Rate of Reading Comprehension Test Achievement in the Pre-Test.

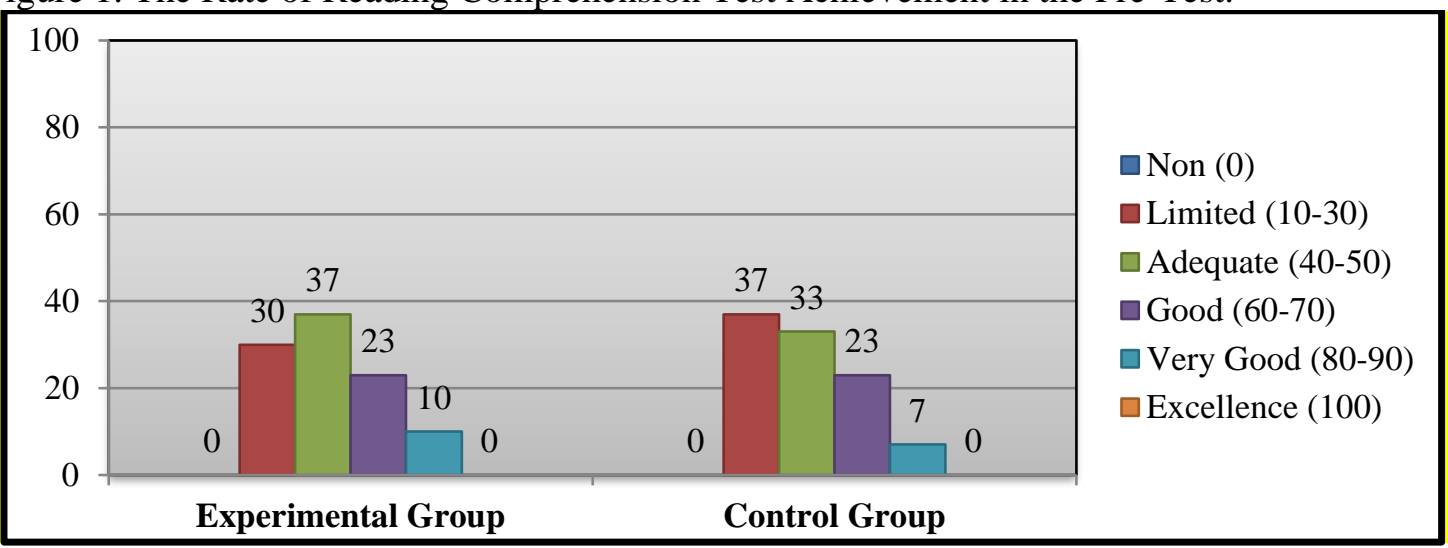

Figure 1 shows that experimental and the control groups differentiate the number of students on each classification before treatment. In the experimental group (0\%) categorized into the non-scorable achievement, some 30\% were in the limited achievement, $37 \%$ of students classified into the adequate, and $23 \%$ were categorized into good, $10 \%$ very good, $0 \%$ ranked as excellence. On the other side, in the control group, $0 \%$ of students onto the nonscorable achievement, $37 \%$ students were in the limited, $33 \%$ classified as adequate, $23 \%$ of students were in good classification, some $7 \%$ were in the very good, and $0 \%$ categorized as excellence.

Figure 2. The Rate of Reading Comprehension Test Achievement in the Post-Test.

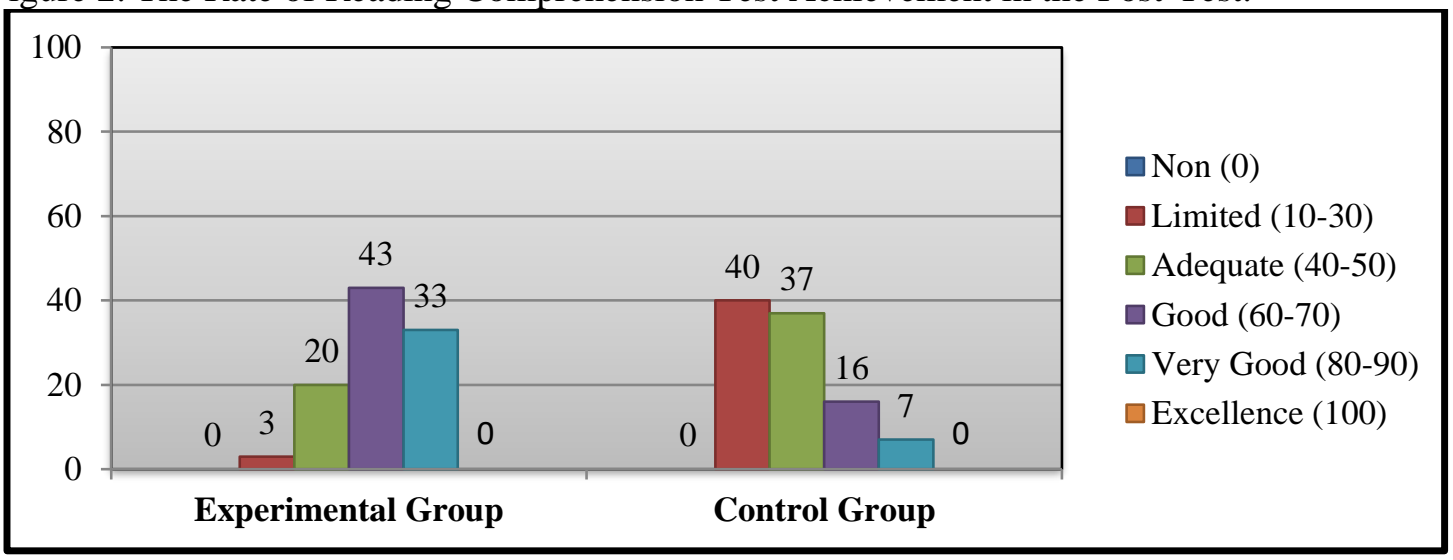

The figure 2 display the different description on reading comprehension test achievement after given treatment, in the experimental group, no one student $(0 \%)$ categorized into the non-scorable achievement, some $3 \%$ were in the limited, $20 \%$ of students classified as adequate, $43 \%$ of the student categorized into good, 33\% very good, $0 \%$ categorized as excellence. Furthermore, in the control group, $0 \%$ of students in the non-scorable achievement, $40 \%$ students were in the limited, $37 \%$ classified as adequate, $16 \%$ of students were in good classification, some $7 \%$ were in the very good, and $0 \%$ categorized as an excellence.

Table 1. The Mean Score and The Standard Deviation of Reading Comprehension Test. 


\begin{tabular}{cllcc}
\hline \multicolumn{1}{c}{ Session } & \multicolumn{1}{c}{ Group } & N & Mean Score & Standard Deviation \\
\hline Pre-test & Experimental & 30 & 49.60 & 15.207 \\
& Control & 30 & 44.40 & 17.046 \\
Post-test & Experimental & 30 & 68.00 & 14.855 \\
& Control & 30 & 48.80 & 16.522 \\
\hline
\end{tabular}

Figure 3. The Mean Score of the Students' Reading Comprehension Test.

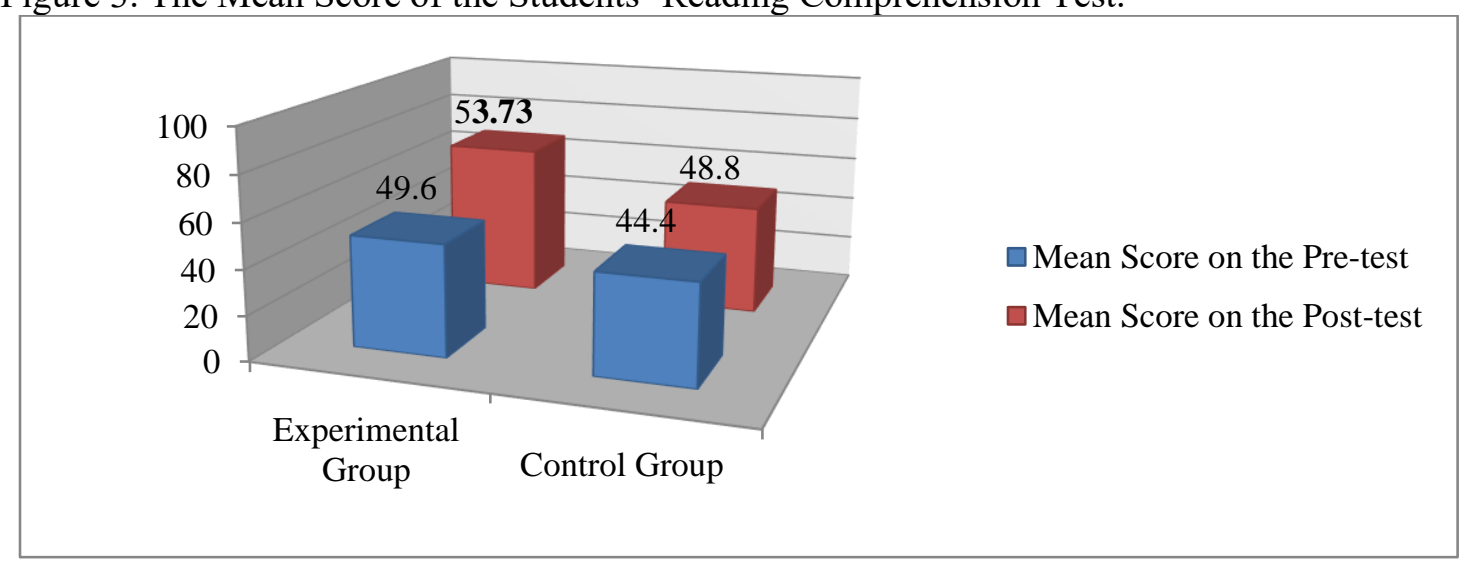

Table 1 presents the mean score of the students' pre-test in the experimental group was 49.60, and its standard deviation was 15.207, while the mean score in the control group was 44.40, and its standard deviation was 17.046. The differences mean score between both groups was 5.2. Again, after the series of treatments have done, the mean score of both groups was different. The mean score of the students' post-test in the experimental group was 68.00 , with a standard deviation of 14.855. On the other side, the mean score of the students' post-test in the control group was 48.80, with the standard deviation 16.522. The difference in score between both groups was 19.2, and it means that the mean score of the experimental group is higher than the control group $(68.00>48.80)$. The mean score of students' in the experimental group was greater than the control group, it is deduced that audiobooks affect students' reading comprehension.

Table 2. The test of significance ( Paired Samples T-Test)

\begin{tabular}{lccccc}
\hline \multicolumn{1}{c}{ Session } & N & t & $\begin{array}{c}\text { P- } \\
\text { Value }\end{array}$ & df & Remarks \\
\hline $\begin{array}{l}\text { Pre-test and Post-test } \\
\text { of Experimental Group }\end{array}$ & 30 & 14.699 & .000 & 29 & Significantly Improved \\
$\begin{array}{l}\text { Pre-test and Post-test } \\
\text { of Control Group }\end{array}$ & 30 & 3.973 & .000 & 29 & Significantly Improved \\
\hline
\end{tabular}

Table 2. presents the $\mathrm{p}$-value of the experimental group is $\alpha(0.000<0.005)$. It indicates that there is a significant difference result between pre-test and post-test in the experimental group. The hypothesis testing results was found that $\mathrm{t}$-value $=14.699$ was higher than $\mathrm{t}$-table $=$ $2.045(\mathrm{p}=.000, \mathrm{df}=29)$. The comparison between the values indicated that the $\mathrm{t}$-value was higher than the t-table. So, the null hypothesis (Ho) Audiobooks did not affect the reading comprehension of the eleventh-grade students of SMA Negeri 2 Buru rejected.

In contrast, the alternative hypothesis (Ha) Audiobooks affected the reading comprehension of the eleventh-grade students of SMA Negeri 2 Buru accepted. Moreover, it is found that the $\mathrm{p}$-value in the control group is smaller than $\alpha(0.000<0.005)$. It indicates that there is also significant differences between pre-test and post-test in the control group. It means that by using textbooks in the reading, the process has also improved students' reading comprehension achievement. 
Table 3. The Probability Value of the T-Test (Independent Sample T-Test)

\begin{tabular}{|c|c|c|c|c|c|}
\hline Session & $\mathrm{N}$ & $\mathrm{t}$ & P-Value & $\mathrm{df}$ & Remarks \\
\hline $\begin{array}{l}\text { Pre-test of } \\
\text { Experimental and the } \\
\text { Control Group }\end{array}$ & 30 & 1.247 & .217 & 58 & $\begin{array}{c}\text { There is no significance } \\
\text { differences }\end{array}$ \\
\hline $\begin{array}{l}\text { Post-test of } \\
\text { Experimental and the } \\
\text { Control Group }\end{array}$ & 30 & 4.217 & .000 & 58 & $\begin{array}{l}\text { There is significance } \\
\text { differences }\end{array}$ \\
\hline
\end{tabular}

Table 3. has described that the p-value of the pre-test is .217 , and the level of significance is 0.00 , in this case, the p-value is greater than $\alpha(.217>.000)$. It means that there are no significant differences in reading comprehension ability between the experimental and the control group before treatment is conducted. Furthermore, the p-value in the post-test is .000 , and the level of significance is $\alpha 0.05$, the $\mathrm{p}$-value is smaller than $\alpha(.000<0.05)$. It indicates that audiobooks and textbooks have significantly affected students' reading comprehension. Even though the experimental group reading comprehension achievements are higher than the control group, it can be concluded that the use of audiobooks in the teaching of reading is better than the use of textbooks.

\section{Students' Interest Towards Audiobooks on the Teaching of Reading}

\section{a. Stimulating Reading Experiences}

"I felt more enthusiastic in reading English by using Audiobook than reading by using the English textbooks" (Open-ended questions of ML 2020).“...It is exciting because audiobooks are very good at the English reading lesson." "Audiobook helps us read better by understanding each narrated word, and it also motivates us to learn English at wherever we can" (Open-ended questions of MAA 2020). "Very enthusiastic because this learning strategy can develop students reading interest" (Open-ended Questions NIO 2020).

"Yes... it is because reading by using audiobooks is better, and it can increase our English and draw our' attention to learn" (Open-ended questions of NSM 2020).

"It is the perfect media for facilitating students to learn English, because of it is fascinating and motivates students to read English very often" (Open-ended questions of RAA 2020). ."... Audiobook in the reading is quite fun, not dull and it improved my reading skills". (Open-ended questions of STA 2020).

b. Challenging Reading Atmosphere

"It's exciting learning by audiobooks because it is testing the ability to read English and makes our brains think harder" (Open-ended questions of UK 2020).

"...In my opinion, learning by using audiobooks is very challenging because it trained us to be concentrated to read" (Open-ended questions of WI 2020). "Reading through audiobook has improved my reading skills, and pushed my brain out loud" (Open-ended questions of AS 2020).

c. Availability Reading Sources

"The audiobook is easy to access and can be read repeatedly" (Open-ended questions of FFT 2020)."...We can listen to the Audiobook anywhere" (Openended questions of LOAS 2020). "We can read and listen to the audiobook material at any time, even when we are off-line" (Open-ended questions of MFH 2020).“... Audiobook has presented a variety of materials that we can read many times to improve our reading ability" (Open-ended RAA 2020) questions.

d. Powerful Reading Tool

"It is exciting to use audiobooks because the lessons are easy to understand, and it improves my reading skills" (Open-ended questions of SB 2020).“...Audiobooks are enhancing our ability to read and expanding our knowledge and vocabulary" (Open-ended questions of SPR 2020). 
"Audiobooks are improving our reading skills and deepen our understanding of reading subjects" (Open-ended questions of SK 2020).“...Audiobooks are good to be used in the learning process either at school or outside the school" (Open-ended questions of RAP 2020).

e. An Innovative Reading Strategy

"Audiobooks is very different than reading by using printed books before" (Openended questions of VR 2020). "...Audiobooks are an exciting way in reading because we can learn by utilizing mobile phone technology" (Open-ended questions of WNB 2020).“...Audiobooks are quite interesting where we can learn English using Android" (Open-ended questions of FAS 2020).

"Audiobooks are cool and very well to be applied in pandemic conditions as happening now" (Open-ended questions of LOSK 2020)."... It is perfect to support students in improving their reading skills, especially in pandemic conditions like now where all the learning processes go through online" (Open-ended questions of AR 2020).

\section{Discussions}

After given treatment, this study has found a statistically significant difference between the reading comprehension achievements of both groups in the post-test. Considering the research hypothesis, Ha: Audiobook affect the reading comprehension of the eleventh- grade students of SMA Negeri 2 Buru. Based on the results of table 1 the mean score and the standard deviation of reading comprehension test before and after treatment in both groups, table 2 the p-value of paired samples t-test, and table 3 the probability value of the independent sample $t-$ test. Audiobooks and textbooks have significantly affected students' reading comprehension. However, the experimental group reading comprehension achievements are higher than the control group, it can be deduced that the use of audiobooks in the teaching of reading is superior to the use of textbooks, therefore the alternative hypothesis $\mathrm{Ha}$ is accepted. This finding is in line with listening while reading, which will lead students to be ready and comprehend its content, and in this particular way, has slowly developed the English competence of the students (Chen, 2004; Imawan \& Ashadi, 2019; Kuzmičová, 2016).

The students' responses to the open-ended questions provided intriguing insights into the effectiveness of audiobooks on reading comprehension. The majority of the students felt that the audiobooks are stimulating, motivating them to learn reading. This finding is in line with (Brock, 2013; Hidi, 2001) if students who have interests in activities or topics focus on their attention, persist for more extended periods, and enjoy their engagements are more likely to interest in reading. The narrator's speech rate may become a new language input for some students. As it directly worked as in the listening class process, its speech rate significantly influenced their comprehension. Students' auditory discrimination and word recognition skills allowed them to gain in matching both written and spoken language. EFL learners felt easy to catch the word and information by the narrator's speech rate (Renandya \& Farrell, 2011). Briefly, teachers have to make their students be accustom to the involvement of authentic materials on their learning activity, and by getting used to the spoken rate, rhythm, and the natural flow of the language can be facilitated to improve their comprehension(CHANG, 2011; Juvrianto, Atmowardoyo, \& Weda, 2018).

Challenging the reading atmosphere has increased students' engagement in the reading material. Combining the audio and digital texts presented by the audiobooks has challenged students to read thoughtfully and intensively. This scientific fact was in line with Serafini (2004) as media the audiobook gave the two most effective models for teaching reading, storytelling, and reading aloud, which have familiarized students with the "sound and sense" of written language being learned. In addition, the audiobooks help readers gain skills in many ways, such as recalling details, understanding sequence, making predictions, drawing conclusions, making inferences, and retelling. Thus, audiobooks replaced traditional reading comprehension activity by answering reading material exercises through the audio and its digital text(Stern, 
The availability of reading sources of audiobooks have facilitated students to learn beyond the classroom. Students can access the audiobooks whenever they want. They can easily access each of their materials based on their need. Aditomo \& Hasugian (2018) declared that the availability of new reading materials both inside and outside the home could enhance students' interest in reading to expand their vocabulary knowledge, which catalyzes the acquisition of more complex literacy to build their comprehension ability.

As a powerful tool, audiobooks can benefit everyone who is struggling readers by increasing comprehension of the text. Using audiobooks in reading activities has facilitated students to get the new vocabulary, and the concept of its materials through a variety of different reading narration has been provided. The audiobooks make students' accustomed to being more active readers and allowed them to expand their academic prowess. The benefits of reading-listening to an audiobook are expanding students' vocabulary, pronunciation, and comprehension because listening to it just like reading a book (Of, Learners, On, Books, \& Efl, n.d.).

An innovative reading strategy offered extended reading activities differently. Audiobooks can read and listen while doing other. We don't need to carry a physical book, so reading activity can be done everywhere we want. It is because audiobooks can be accessed online. This finding is in line with Ammanni \& Aparanjani (2016) in their study stated that the audiobooks assisted students in fulfilling their reading needs autonomously because students' can listen to the audiobooks and read their e-book at the same time through their gadgets such as smartphones and android tablets both in online and offline mode. In this 21 st century, teachers and educators need to apply the use of mobile devices as media as well as instructional resources to adjust the previous traditional educational methods to the digital learning environment (Have \& Pedersen, 2015; Luna-Nevarez \& McGovern, 2018).

\section{CONCLUSION}

On the whole, the result of this research pointed out that the audiobook not only aids the eleventh-grade students of SMA Negeri 2 Buru to develop their reading desire to become better readers, but also helps them gain better comprehension in the reading texts. The advantages of audiobook over traditional reading activities, namely, stimulating, challenging, availability, powerful, and innovative, have been producing some positive interests for learners in learners' self-study to get better reading comprehension ability. As students and teachers listen to the audiobook, they can discuss strategies for analyzing and comprehending the story. Also, the significant implication of this study is that audiobook technology could be an instructional strategy, either it working as the media to give valuable input for students in enhancing their reading comprehension ability.

Dealing with the conclusion, the researcher provided some suggestions that may be valuable for those involved in the English teaching and learning process. Audiobooks can facilitate the reading of, e.g.,descriptive, recount, narrative, analytical exposition, explanation, procedures, news items in the context of interpersonal, transactional, special functional, and functional texts which contain social functions, text structures, and linguistic elements. Among many, audiobooks are one of the many online media that can be accessed to use in the teaching of reading. To find the most appropriate audiobooks for the students, it is suggested to access, http://esl-bits.net/, https://librivox.org/, https://www.digitalbook.io/, and many kinds of audiobooks which have been provided on the website as the instructional, strategy, or medium inside and outside the classroom because making this effort will help students and entertain them while reading to enhance their comprehension ability.

\section{Acknowledgements}

My great gratitude goes to the Ministry of Education and Culture of the Republic of Indonesia, Directorate General of Higher Education, and the Ministry of Research and Technology/National Agency for Research and Innovation of the Republic of Indonesia for 
providing full financial support to all activities on this novice lecturer research including authorship, and the publication of this article on the journal.

\section{REFERENCES}

Abukhattala, I. (2013). Krashen's five proposals on language learning: Are they valid in Libyan EFL classes. English Language Teaching, 6(1), 128-131.

Aditomo, A., \& Hasugian, E. J. (2018). Indonesian adolescents' EFL reading comprehension: Gender differences and the influence of parental background. Indonesian Journal of Applied Linguistics, 8(2), 325-335.

Alcantud-Díaz, M., \& Gregori-Signes, C. (2014). Audiobooks: improving fluency and instilling literary skills and education for development Audiolibros: mejorar la fluidez e inculcar habilidades literarias y educación para el desarrollo, 20(January), 111-125. Retrieved from http://dehesa.unex.es/bitstream/handle/10662/4523/1988-

8430_20_111.pdf?sequence $=1 \&$ is Allowed $=\mathrm{y}$

Alsamadani, H. A. (2017). The Effect of Talking Story Books on Saudi Young EFL Learners' Reading Comprehension. English Language Teaching, 10(5), 204.

Ammanni, S., \& Aparanjani, U. (2016). The role of ICT in English language teaching and learning. International Journal of Scientific and Engineering Research, 7(7), 1-7. Retrieved from https://www.ijser.org/researchpaper/THE-ROLE-OF-ICT-IN-ENGLISHLANGUAGE-TEACHING-AND-LEARNING.pdf

Atmowardoyo, H. (2018). Research Methods in TEFL Studies: Descriptive Research, Case Study, Error Analysis, and R \& D. Journal of Language Teaching and Research.

Asrul, Ananda, R., \& Rosinta. (2014). Evaluasi Pembajalaran. Ciptapustaka Media.

Ayunda, A. N. (2013). the Effect of Audiobook Use on Efl Students '. Journal on English as a Foreign Language.

Baird, S. G. (n.d.). Audiobook collections \& services.

Brock, R. M. (2013). Audiobooks and attitudes: An examination of school librarians' perspectives. ProQuest Dissertations and Theses.

Broughton, G., Brumfit, C., Flavell, R., Hill, P., \& Pincas, A. (2003). Teaching English as a Foreign Language. London and New York: Taylor and Francis e Library.

Buzan, T. (2003). The Speed Reading Book. Woodlands: BBC Worldwide Limited.

Cahyono, B. Y. (2009). the Teaching of Efl Listening in the Indonesian Context: the State of the Art. TEFLIN Journal, 20(2), 36-58.

Casbergue, R. M., \& Harris, K. (1996). Listening and literacy: Audiobooks in the reading program. Reading Horizons, 37(1), 48-59.

CHANG, A. C.-S. (2011). Audiobooks : Listening Fluency and Vocabulary Gain. Asian Journal of English Language Teaching, 21, 43-64.

Chen, S.-H. L. (2004). Improving Reading Skills through Audiobooks. School Library Media Activities Monthly.

Corbin, J., \& Strauss, A. (2008). Basics of Qualitative Research: Techniques and Procedures for Developing Grounded Theory (3rd ed.). United States of America: Sage Publications, Inc.

Delfi, S., \& Yamat, H. (2017). Extensive Reading in Developing Language Competency for Indonesian EFL Learners Majoring in English. IJELTAL (Indonesian Journal of English Language Teaching and Applied Linguistics), 1(2), 153.

Gay, L. R., Mills, G. E., \& Airasian, P. (2012). Educational Research Competencies for Analysis and Applications (10th Edition ed.). United States of America: Pearson Education, Inc.

Gilakjani, A. P., \& Sabouri, N. B. (2016). A Study of Factors Affecting EFL Learners ' Reading Comprehension Skill and the Strategies for Improvement, 6(5), 180-187.

Grabe, W., \& Stoller, F. L. (2013). Teaching and researching reading, second edition. Teaching and Researching Reading, Second Edition.

Grellet, F. (1981). Developing Reading Skills: A Practical Guide to Reading Comprehension Exercises 
Gunduz, N. (2006). Contribution of E-Audiobooks and Podcast to EFL Listening Classes. Edebiyat Fakültesi Dergisi/ Joumal of Faculty of Letters , 249-259.

Habók, A., Magyar, A., \& Hui, S. K. F. (2019). The effects of EFL reading comprehension and certain learning-related factors on EFL learners' reading strategy use. Cogent Education, 6(1). Cogent. Retrieved from https://doi.org/10.1080/2331186X.2019.1616522

Hall, W. S. (1989). Reading Comprehension. American Psychologist.

Have, I., \& Pedersen, B. S. (2015). Digital audiobooks: New media, users, and experiences. Digital Audiobooks: New Media, Users, and Experiences.

Hidi, S. (2001). Claiming place: biracial young adults of the post-Civil Rights era. Choice Reviews Online, 38(11), 38-6500-38-6500.

Imawan, M. R., \& Ashadi, A. (2019). Audiobooks for Assisting EFL Students in Reading Independently. Journal of English Language Teaching and Linguistics, 4(1), 77.

Jabu, B., \& Muliati, A. (2019). Baso Jabu, 6(1).

Juvrianto, Atmowardoyo, H., \& Weda, S. (2018). The Use of Digital Storytelling in Teaching Listening Comprehension: An Experimental Study on the Eighth Grade Students of SMP Negeri 4 Parepare. ELT Worldwide Journal.

Kartal, G., \& Simsek, H. (2017). The Effects of Audiobooks on EFL Students' Listening Comprehension. The Reading Matrix, 17(1), 112-123.

Kasim, U., \& Raisha, S. (2017). EFL Students' Reading Comprehension Problems: Linguistic and Non-Linguistic Complexities. English Education Journal (EEJ) , 8 (3), 308-321.

Krashen, S. D. (1982). Principles and Practice in Second Language Acquisition. The Modern Language Journal (Vol. 67). Retrieved from http://aces.ir/attachments/22d1286622494communicative-approach-stephencrashen.pdf\%5Cnhttp://www.jstor.org/stable/328293?origin=crossref

Kuzmičová, A. (2016). Audiobooks and Print Narrative: Similarities in Text Experience. Audionarratology.

Larson, L. C. (2015). E-books and audiobooks: Extending the digital reading experience. Reading Teacher, 69(2), 169-177.

Lin, L.-F. (2010). Senior High School Students' Reading Comprehension of Graded Readers. Journal of Language Teaching and Research.

Luna-Nevarez, C., \& McGovern, E. (2018). On the Use of Mobile Apps in Education: The Impact of Digital Magazines on Student Learning. Journal of Educational Technology Systems, 47(1), 17-31.

Mistar, J., Zuhairi, A., \& Yanti, N. (2016). Strategies Training in the Teaching of Reading Comprehension for EFL Learners in Indonesia. English Language Teaching.

Montgomery, J. (2009). Using Audio Books to Improve Reading and Academic Performance. Online Submission, 1-13.

Moore, J., \& Cahill, M. (2016). Audiobooks: Legitimate "reading" material for adolescents? School Library Research, 19(January).

Of, P., Learners, E. F. L., On, B., Books, A., \& Efl, I. N. (n.d.). PRODUCTION OF EFL LEARNERS BASED ON, 1-83.

Pardede, P. (2006). A Review on Reading Theories and its Implication to the Teaching of Reading. UKI: ELT and Edu A cyber ELT \& Edu service from Universitas Kristen Indonesia [online], (November), 1-14.

Pardede, P. (2019). Print vs Digital Reading Comprehension in EFL. Journal of English Teaching, 5(2), 77-90.

Pearson, P. D., \& Cervetti, G. N. (2015). Fifty Years of Reading Comprehension Theory and Practice. Research-Based Practices for Teaching Common Core Literacy, (April), 1-40.

Pusat Penilaian Pendidikan Kementerian Pendidikan dan Kebudayaan. (2019). Retrieved August 04, 2019, from http://puspendik.kemdikbud.go.id: http://puspendik.kemdikbud.go.id/hasil-un/

Renandya, W. A. (2015). Reading in a foreign language: What else is important besides skills and strategies ?, 81-94.

Renandya, W. A., \& Farrell, T. S. C. (2011). “Teacher, the tape is too fast!” Extensive listening 
in ELT. ELT Journal, 65(1), 52-59.

Ryan Wagar, C. (2016). The Impact of Audiobooks on Reading Comprehension and Enjoyment, (June). Retrieved from https://www.researchgate.net/publication/304674071

Salikin, H., Bin-Tahir, S. Z., Kusumaningputri, R., \& Yuliandari, D. P. (2017). The Indonesian EFL Learners' Motivation in Reading. English Language Teaching.

Serafini, F. (2004). Audiobooks and Literacy. New York, NY 10019: (c) 2004 Listening Library, A Division of Random House, Inc.

Stern, C. (2011). The role of audiobooks in academic libraries. College and Undergraduate Libraries, 18(1), 77-91.

Stevens, E. A., Walker, M. A., \& Vaughn, S. (2017). The Effects of Reading Fluency Interventions on the Reading Fluency and Reading Comprehension Performance of Elementary Students With Learning Disabilities: A Synthesis of the Research from 2001 to 2014. Journal of Learning Disabilities.

Talalakina, E. V. (1989). Audiobook in Advanced ESL Classroom: Developing Critical Listening. ICT for Language Learning.

Thooft, N. A. (2012). The Effect of Audio Books on Reading Comprehension and Motivation A Master's Project Report Submitted in Partial Fulfillment of The Requirements for the, (November).

Ulu, M. (2017). The Effect of Reading Comprehension and Problem Solving Strategies on Classifying Elementary 4th Grade Students with High and Low Problem Solving Success. Journal of Education and Training Studies.

Ur, P. (1999). A Course in Language Teaching Trainee Book. A Course in Language Teaching Trainee Book.

Vernon, E. J. (2015). Using Audiobooks to Promote Comprehension of Cause-Effect Relationships in Social Studies Texts.

Whittingham, J., Huffman, S., Christensen, R., \& McAllister, T. (2013). Use of audiobooks in a school library and positive effects of struggling readers' participation in a librarysponsored audiobook club. School Library Research, 16(Benson 2011).

Woodall, B. (2010). Simultaneous Listening and Reading in ESL: Helping Second Language Learners Read (and Enjoy Reading) More Efficiently. TESOL Journal, 1(2), 186-205. 